OPEN ACCESS

Edited by:

Tiago F. Outeiro,

University Medical Center

Goettingen, Germany

Reviewed by:

Qitao Ran,

The University of Texas Health

Science Center at San Antonio,

United States

Ju Gao,

Case Western Reserve University, United States

${ }^{*}$ Correspondence: Po-Wah So

po-wah.so@kcl.ac.uk

Received: 20 April 2020 Accepted: 05 June 2020

Published: 14 July 2020

Citation:

Ashraf A and So P-W (2020) Spotlight on Ferroptosis: Iron-Dependent Cell Death in Alzheimer's Disease. Front. Aging Neurosci. 12:196. doi: 10.3389/fnagi.2020.00196

\section{Spotlight on Ferroptosis: Iron-Dependent Cell Death in Alzheimer's Disease}

\author{
Azhaar Ashraf and Po-Wah So* \\ Department of Neuroimaging, Institute of Psychiatry, Psychology, and Neuroscience, King's College London, London, \\ United Kingdom
}

Alzheimer's disease is an emerging global epidemic that is becoming increasingly unsustainable. Most of the clinical trials have been centered around targeting $\beta$-amyloid and have met with limited success. There is a great impetus to identify alternative drug targets. Iron appears to be the common theme prevalent across neurodegenerative diseases. Iron has been shown to promote aggregation and pathogenicity of the characteristic aberrant proteins, $\beta$-amyloid, tau, $\alpha$-synuclein, and TDP43, in these diseases. Further support for the involvement of iron in pathogenesis is provided by the recent discovery of a new form of cell death, ferroptosis. Arising from iron-dependent lipid peroxidation, ferroptosis is augmented in conditions of cysteine deficiency and glutathione peroxidase-4 inactivation. Here, we review clinical trials that provide the rationale for targeting ferroptosis to delay the pathogenesis of Alzheimer's disease (AD), potentially of relevance to other neurodegenerative diseases.

Keywords: Alzheimer's disease, cystine/glutamate antiporter, ferroptosis, glutathione peroxidase-4, iron, lipid peroxidation

\section{INTRODUCTION}

Alzheimer's disease $(\mathrm{AD})$ is increasing at an alarming rate and is an emerging epidemic. Current incidence world-wide is $\sim 50$ million and expected to triple by 2050 . The economic costs of AD, the most common cause of dementia, are $\$ 260$ billion and projected to reach $\$ 1167$ billion by 2050 (Alzheimer's Disease International, 2019). Thus, there is a great impetus to develop treatments to delay $\mathrm{AD}$ pathogenesis.

$\mathrm{AD}$ is classically defined by $\beta$-amyloid plaques and neurofibrillary tangles. Many clinical trials directed at lowering $\beta$-amyloid have met with limited success. One reason for the failures could be that $50 \%$ of AD patients exhibit $\alpha$-synuclein pathology, while $30 \%$ show TDP43 pathology (Robinson et al., 2018). We suggest sole targeting of $\beta$-amyloid or tau may not be fruitful in AD as contributions from $\alpha$-synuclein and TDP43 significantly modify disease pathogenesis-alternative disease-modifying targets are crucial.

Iron dyshomeostasis appears to be a common theme, unifying neurodegenerative diseases including $\mathrm{AD}$, Lewy Body disease, and frontotemporal dementia (FTD). Iron has been shown to promote the aggregation and pathogenicity of $\beta$-amyloid (Rottkamp et al., 2001), tau (Sayre et al., 2000), $\alpha$-synuclein (Xiao et al., 2018) and indirectly, TDP43 (Jeong et al., 2009; Joppe et al., 2019). We hypothesize that iron dyshomeostasis is widespread in neurodegenerative diseases and ensuing 
mechanisms underlying iron toxicity may provide novel disease targets. This unified and unique approach-targeting iron dyshomeostasis-is likely to benefit dementia patients, the majority of which are affected by $\mathrm{AD}$, but also orphan diseases e.g., FTD. Here, we review the evidence from clinical trials concerning the rationale of targeting ferroptosis for $\mathrm{AD}$.

\section{IMPORTANCE OF IRON HOMEOSTASIS}

Iron is an essential metal for neurons, required for mitochondria respiration as well as other processes e.g., myelination and neurotransmitter synthesis (Ward et al., 2014; Ashraf et al., 2018). Iron can exist in oxidized and reduced states, ferric iron $\left(\mathrm{Fe}^{3+}\right)$, and ferrous iron $\left(\mathrm{Fe}^{2+}\right)$, respectively. Ferrous iron predominantly contributes to the cellular labile iron pool (LIP), participating in key metabolic reactions but also toxic reactions that can lead to oxidative stress and eventually cell death. Excessive build-up of LIP is avoided by sequestration of iron, in a bioavailable yet non-toxic form, by ferritin (Harrison and Arosio, 1996). Ferritin works in concert with ferroportin, the only known cellular iron exporter, aided by the ferroxidase, ceruloplasmin, to regulate LIP (De Domenico et al., 2007). Tight regulation of iron metabolism is pivotal to ensure neuronal homeostasis-both iron excess and deficiency are associated with neurodegeneration (Goodman, 1953; Youdim, 2008; Ashraf et al., 2019).

\section{LABILE IRON POOL AND ITS ROLE IN FERROPTOSIS}

Increased LIP can lead to the generation of reactive oxygen species via Fenton reaction, eventually resulting in catastrophic membrane rupture (Kakhlon and Cabantchik, 2002; Petrat et al., 2002; Kruszewski, 2003). Coincident depletion of glutathione (GSH) or inactivation of glutathione peroxidase-4 (GPX4) leads to a newly characterized form of cell death, coined ferroptosis (Dixon et al., 2012). Neuron-specific GPX4 depletion has been shown to lead to neurodegeneration, highlighting this pathway as a future therapeutic target (Seiler et al., 2008). GPX4 is a master regulator of ferroptosis by functioning as a lipid repair enzyme and detoxifying lipid hydroperoxides, utilizing GSH as an essential cofactor. GSH synthesis/levels are reliant on cellular cysteine availability. Cysteine is imported into cells in its oxidized form, cystine, in exchange for glutamate by the cystine/glutamate antiporter (system $\mathrm{X}_{\mathrm{c}}^{-}$). Increased extracellular glutamate in concert with glutaminolysis may contribute to detrimental excitotoxicity (Dixon et al., 2012; Gao et al., 2015; Stockwell et al., 2017; Ashraf et al., 2020), and possibly a feature of ferroptosis.

System $\mathrm{X}_{\mathrm{c}}^{-}$-inhibition attenuates GSH levels, inactivates GPX4, and enhances lipid peroxidation (Dixon et al., 2012). Polyunsaturated fatty acids (PUFAs), especially arachidonic acid, in membrane lipids are preferentially oxidized during ferroptosis. Arachidonic acid is activated by Acyl-CoA Synthetase Long-Chain Family Member 4 (ACSL4) for incorporation into phosphatidylethanolamines (and membranes). Oxidized phosphatidylethanolamines are proximate executors of ferroptosis and hence ACSL4 expression modulates ferroptosis susceptibility (Doll et al., 2017). Notably, long-term use of pioglitazone, recently characterized to be an ACSL4 inhibitor, is associated with attenuated risk of dementia in type 2 diabetes mellitus patients (Heneka et al., 2015).

While iron enhances lipid peroxidation via the non-enzymatic Fenton reaction, lipid peroxidation can also be catalyzed by specific non-heme, iron-containing lipoxygenases, such lipoxygenases also confer vulnerability to ferroptosis (Yang et al., 2016). GPX4-ablation in mice and cells revealed downstream 12/15-lipoxygenase-derived lipid peroxidation, trigger apoptosis-inducing factor-mediated cell death, and subsequent oxidative stress (Seiler et al., 2008). Moreover, neuron-specific ablation of GPX4 in the forebrain (cerebral cortex and hippocampus) was associated with an increase in markers associated with ferroptosis including increased lipid peroxidation, extracellular-regulated kinase (ERK) 4 and neuroinflammation (Hambright et al., 2017). The susceptibility of $\mathrm{AD}$ vulnerable neuronal populations to ferroptosis is suggestive of its role in $\mathrm{AD}$.

During ferroptosis, cytosolic ferritin may undergo lysosomal breakdown (ferritinophagy) to further contribute to LIP - ferritinophagy appears to augment cysteine deficiencyinduced ferroptosis (Gao et al., 2016; Hou et al., 2016). While total cellular iron levels may be unchanged, an augmented LIP renders cells more susceptible to ferroptosis. The increased influx of iron into the mitochondria induces the accumulation of reactive oxygen species and lipid peroxidation. Lipid peroxidation is enhanced in cysteine deprivation via hyperpolarized mitochondrial membrane potential (Gao et al., 2019). The distinguishing features of ferroptosis are evident cytologically, in the form of condensed mitochondrial membrane and mitochondrial volume shrinkage (Yagoda et al., 2007; Stockwell et al., 2017). Interestingly, genetic factors including TDP43, amyloid precursor protein (APP), APOE may play a pivotal role in modifying mitochondrial functionality. Suppressing localization of TDP43 in the mitochondria inhibited TDP43-mediated neurotoxicity (Wang et al., 2016). Electron microscopic analysis of FTD and amyotrophic lateral sclerosis patients with TDP43 pathology revealed prominent mitochondrial impairment, including abnormal and/or depleted cristae, concordant with ultrastructural changes observed in both cellular and animal models of TDP43 proteinopathy (Wang et al., 2019). Mechanistically, TDP43 expression attenuated mitochondrial membrane potential, suppressed mitochondrial complex I activity, and impaired mitochondrial ATP synthesis. Moreover, downregulation of LonP1 (mitochondrial protease) augmented TDP43 levels which exacerbated TDP43-induced mitochondrial damage and neurodegeneration (Wang et al., 2019).

Mitochondria isolated from $\mathrm{AD}$ brains show increased accumulation of APP and $\beta$-amyloid associated with reduced ability of mitochondria to import nuclear-encoded proteins and impaired cytochrome c oxidase activity (Devi et al., 2006; Hansson Petersen et al., 2008). Tau mutant mice and triple transgenic mice harboring APP and tau mutations demonstrated impaired mitochondrial respiration, increased production of reactive oxygen species, and augmented oxidative 
stress (David et al., 2005; Rhein et al., 2009; Yao et al., 2009). APOE 44 genotype is a major susceptibility risk locus particularly in $\mathrm{AD}$, associated with enhanced mitochondrial fusion and decreased fission (Simonovitch et al., 2019). APOE4 has been found to negatively modify effects of iron on brain functionality before the manifestation of cognitive impairment (Kagerer et al., 2020), and can regulate iron-homeostatic proteins like ferritin to increase an individual's risk of conversion to AD (Ayton et al., 2015). Combining the different lines of evidence, a pivotal involvement of proteinopathies is indicated in inducing iron dyshomeostasis, lipid peroxidation, and mitochondrial damage which are reminiscent of changes consistent with ferroptosis. This proposition awaits experimental validation to elucidate a direct role of the misfolded proteins in ferroptosis in the context of neurodegenerative diseases.

\section{EVIDENCE FOR FERROPTOSIS IN AD}

\section{Iron Chelators}

A 2-year Phase II clinical trial reported desferrioxamine, an iron chelator, attenuates cognitive decline in $\mathrm{AD}$ (Crapper McLachlan et al., 1991). However, desferrioxamine treatment was not further pursued owing to its lack of blood-brain-barrier (BBB) penetrance. Intranasal deferoxamine overcomes this problem and shown to improve cognition in a mouse AD model (Fine et al., 2012, 2015). Iron chelation attenuated oxidative stress, lowered $\beta$-amyloid load, and tau hyperphosphorylation (by inhibition of cyclin-dependent kinase-5 and glycogen synthase kinase activity; Guo et al., 2013a; Guo et al., 2013b).

Deferiprone is an orally active, brain penetrant iron-chelator, approved for use in $\beta$-thalassemia, currently, undergoing a Phase II clinical trial in mild cognitive impairment (MCI) and $\mathrm{AD}$ (Deferiprone to Delay Dementia-clinicaltrials.gov identifier: NCT03235686; Nikseresht et al., 2019). This trial was preceded by Phase II clinical trials on Parkinson's disease (PD) which showed reduced brain iron assessed by magnetic resonance imaging (MRI) and cerebrospinal fluid (CSF) ferritin and concomitant ameliorated motor deficits (Table 1, Devos et al., 2014; MartinBastida et al., 2017).

Although chelating the LIP in the brain is a tempting strategy, many challenges warrant mention. Since iron is an essential cofactor in multi-fold cellular processes, iron-chelation can have off-target effects and potentially cause untoward effects.

TABLE 1 | Clinical trials involving iron-chelators in Alzheimer's disease (AD) and Parkinson's disease (PD).

\begin{tabular}{|c|c|c|c|c|c|c|}
\hline Study & $\begin{array}{l}\text { Study } \\
\text { population }\end{array}$ & Treatment & Dose & $\begin{array}{l}\text { Duration } \\
\text { (years) }\end{array}$ & Outcome measures & Results \\
\hline $\begin{array}{l}\text { Crapper } \\
\text { McLachlan } \\
\text { et al. (1991) }\end{array}$ & 48 AD cases & $\begin{array}{l}\text { Iron-chelator } \\
\text { Desferrioxamine }\end{array}$ & $\begin{array}{l}125 \text { mg twice daily } \\
\text { for } 5 \text { days/week } \\
\text { Intramuscular }\end{array}$ & 2 & $\begin{array}{l}\text { Videorecorder home-behavioral } \\
\text { assessment for activities of daily } \\
\text { living } \\
\text { Wechsler Adult Intelligence } \\
\text { Scale-revised } \\
\text { Wechsler Memory Scale form } 1 \\
\text { Western Aphasia Battery }\end{array}$ & $\begin{array}{l}\text { Significant reduction in rate of } \\
\text { decline in activities of daily living } \\
(p=0.03) \text {. } \\
\text { Subjects suffered appetite loss } \\
\text { (4) or had gradual weight loss (1). }\end{array}$ \\
\hline $\begin{array}{l}\text { Devos et al. } \\
\text { (2014) }\end{array}$ & 40 PD cases & $\begin{array}{l}\text { Iron-chelator } \\
\text { Deferiprone }\end{array}$ & $\begin{array}{l}15 \text { mg/kg twice } \\
\text { daily Oral }\end{array}$ & 2 & $\begin{array}{l}\text { Movement Disorders } \\
\text { Society - Unified Parkinson's } \\
\text { Disease Rating Scale } \\
\text { (MDS-UPDRS) } \\
\text { T2* MRI (surrogate measure for iron) } \\
\text { Serum iron, ferritin, transferrin and } \\
\text { ceruloplasmin } \\
\text { CSF iron and ferritin } \\
\text { Plasma and CSF oxidative stress } \\
\text { markers including malonaldehyde, } \\
\text { 8-oxo-7,8-dihydro-2'- } \\
\text { deoxyguanosine and carbonylated } \\
\text { proteins } \\
\text { Plasma and CSF antioxidant } \\
\text { markers including glutathione } \\
\text { peroxidase and superoxide } \\
\text { dismutase }\end{array}$ & $\begin{array}{l}\text { Improved motor performance } \\
(p=0.002) \text {. } \\
\text { Reduced iron in substantia nigra } \\
(p=0.001) \text {. } \\
\text { Reduced CSF and blood ferritin, } \\
\text { and oxidative stress }(p<0.05) \text {. } \\
\text { Improved CSF antioxidant levels } \\
(p<0.05) \text {. } \\
\text { Subjects suffered agranulocytosis } \\
(1) \text { and neutropenia (2). }\end{array}$ \\
\hline $\begin{array}{l}\text { Martin-Bastida } \\
\text { et al. (2017) }\end{array}$ & 22 PD cases & $\begin{array}{l}\text { Iron-chelator } \\
\text { Deferiprone }\end{array}$ & $\begin{array}{l}10 \text { or } 15 \mathrm{mg} / \mathrm{kg} \\
\text { twice daily } \\
\text { Oral }\end{array}$ & 0.5 & $\begin{array}{l}\text { MDS-UPDRS } \\
\text { Mini-mental State of Folstein } \\
\text { (cognitive function) } \\
\text { Montgomery Asberg dementia } \\
\text { rating scale } \\
\text { Parkinson's disease } \\
\text { questionnaire-39 (quality of life) } \\
\text { T2* MRI } \\
\text { Serum iron, hemoglobin and } \\
\text { transferrin } \\
\text { Plasma ferritin, interleukin-6 tumor } \\
\text { necrosis factor alpha }\end{array}$ & $\begin{array}{l}\text { A trend of improved MDS-UPDRS } \\
\text { score, indicative of improved motor } \\
\text { performance. } \\
\text { Reduced dentate and caudate } \\
\text { nucleus iron content ( } p<0.001) \text {. } \\
\text { Subjects reported exacerbation of } \\
\text { pre-existing muscular/joint pain (7), } \\
\text { mild gastro-intestinal upset (3), } \\
\text { neutropenia and were withdrawn } \\
\text { from the study (2) and had } \\
\text { increased liver enzymes (1). }\end{array}$ \\
\hline
\end{tabular}


The most frequent side-effects are gastrointestinal discomfort including nausea, abdominal pain, vomiting, and diarrhea, which range from mild to moderate (Borgna-Pignatti and Marsella, 2015). The most severe adverse effect experienced by patients on iron-chelator therapy is neutropenia (8.5\%) and agranulocytosis (0.9\%; Borgna-Pignatti and Marsella, 2015). Regular weekly monitoring of blood counts (especially of white blood cells) in patients taking deferiprone is essential to monitor side-effects particularly neutropenia and agranulocytosis, and the dosage titrated accordingly. Moreover, periodic hepatic and renal functions should be evaluated, as these organs are major sites of iron metabolism.

\section{Antioxidants}

\section{Vitamin E}

Vitamin $\mathrm{E}$ is the most potent biological lipophilic chain-breaking antioxidant (Stocker, 2007), actually comprising $\alpha$-, $\beta$-, $\gamma$-, and $\delta$-tocopherols and $\alpha-, \beta-, \gamma$-, and $\delta$-tocotrienols. All react with free radicals to yield a non-radical product and a vitamin $\mathrm{E}$ radical with a delocalized and stabilized unpaired electron. The latter then reacts with another free radical or is regenerated by vitamin C (Maguire et al., 1989). Vitamin E neutralizes peroxyl radicals and terminates lipid peroxidation, especially of PUFAs (Brigelius-Flohé, 2009). PUFAs are particularly susceptible to peroxidation due to their high degree of unsaturation and are greatly enriched (25-30\% of total fatty acids; Joffre et al., 2019) in brain cell membranes. Long-term PUFA-supplementation during midlife is associated with decreased $\mathrm{AD}$ risk in pre-symptomatic (Laitinen et al., 2006; Yassine et al., 2017), although a shorter duration study reported no benefits (Andrieu et al., 2017). By protecting cellular membranes against lipid peroxidation, vitamin $\mathrm{E}$ can be considered a disruptor of ferroptosis.

Vitamin E in plasma, serum, and CSF are reduced in AD (de Wilde et al., 2017). Vitamin E ( $\alpha$-tocopherol) supplementation delayed functional decline and reduced caregiver burden in mild to moderate AD (Table 2, Sano et al., 1997; Dysken et al., 2014). Epidemiological studies using older cohorts from the Netherlands and the Cache County (Utah, USA) concluded vitamin $\mathrm{E}$ intake is associated with a lower risk of developing AD (Engelhart et al., 2002; Zandi et al., 2004). A Rotterdam study and Canadian health and aging (1991-2002) study reported attenuated risk of cognitive decline in $\mathrm{AD}$ patients on high vitamin E supplementation (Devore et al., 2010; Basambombo et al., 2017). Conversely, numerous studies have reported vitamin $\mathrm{E}$ does not reduce $\mathrm{AD}$ risk or slow $\mathrm{AD}$ pathogenesis (Masaki et al., 2000; Luchsinger et al., 2003; Petersen et al., 2005; Gray et al., 2008; Kryscio et al., 2017).

Why has vitamin E shown mixed results in clinical trials? While vitamin E supplementation could simply restore vitamin levels in $\mathrm{AD}$, baseline vitamin $\mathrm{E}$ levels are often not checked. Also, vitamin E bioavailability can be variable due to differential gut absorption from competing nutrients e.g., plant sterols; variable brain levels arising from different vitamin $\mathrm{E}$ forms with varying pharmacokinetics and circulating high-density lipoproteins levels, the latter transports and mediates brain

TABLE 2 | Clinical trials involving Vitamin E in Alzheimer's disease (AD), amnestic mild-cognitive impairment (MCl) and cognitively normal.

\begin{tabular}{|c|c|c|c|c|c|c|}
\hline Study & $\begin{array}{l}\text { Study } \\
\text { population }\end{array}$ & Treatment & Dose & $\begin{array}{l}\text { Duration } \\
\text { (years) }\end{array}$ & Outcome measures & Results \\
\hline $\begin{array}{l}\text { Sano et al. } \\
(1997)\end{array}$ & $341 \mathrm{AD}$ cases & $\begin{array}{l}\text { Vitamin E } \\
(\alpha \text {-tocopherol) }\end{array}$ & $\begin{array}{l}2000 \text { IU daily } \\
\text { Oral }\end{array}$ & 2 & $\begin{array}{l}\text { Alzheimer's Disease Cooperative } \\
\text { Study/Activities of Daily Living } \\
\text { (ADCS); } \\
\text { Mini-mental state examination } \\
\text { (MMSE) } \\
\text { Blessed-Dementia scale }\end{array}$ & $\begin{array}{l}\text { Delayed time to occurrence of } \\
\text { clinical outcomes that reflect } \\
\text { substantial functional deterioration } \\
(p=0.001) \text {. } \\
\text { Patients suffered a fall (12); had } \\
\text { syncope (6) and had a dental event } \\
\text { (1). }\end{array}$ \\
\hline $\begin{array}{l}\text { Petersen et al. } \\
\text { (2005) }\end{array}$ & 769 Amnestic MCl cases & Vitamin E & $\begin{array}{l}2000 \text { IU daily } \\
\text { Oral }\end{array}$ & 3 & $\begin{array}{l}\text { Conversion to AD } \\
\text { MMSE Alzheimer Disease } \\
\text { Assessment Scale-Cognitive } \\
\text { Subscale (ADAS-cog) } \\
\text { ADCS } \\
\text { Clinical dementia rating (CDR) } \\
\text { Global Deterioration Scale (GDS) } \\
\text { Neuropsychological battery tests }\end{array}$ & No clinical benefit. \\
\hline $\begin{array}{l}\text { Lloret et al. } \\
\text { (2009) }\end{array}$ & 33 AD cases & $\begin{array}{l}\text { Vitamin E } \\
(\alpha \text {-tocopherol) }\end{array}$ & $\begin{array}{l}800 \text { IU daily } \\
\text { Oral }\end{array}$ & 0.5 & $\begin{array}{l}\text { MMSE } \\
\text { Blessed-Dementia Scale } \\
\text { Clock drawing test } \\
\text { Blood total glutathione levels and } \\
\text { oxidized glutathione Blood } \\
\text { malondialdehyde }\end{array}$ & $\begin{array}{l}\text { Vitamin E responders showed } \\
\text { significantly decreased oxidative } \\
\text { stress and improved cognitive } \\
\text { performance }(p<0.05) \text {. } \\
\text { Non-responders to Vitamin E } \\
\text { showed significant decline in } \\
\text { cognition }(p<0.02) \text {. }\end{array}$ \\
\hline $\begin{array}{l}\text { Dysken et al. } \\
(2014)\end{array}$ & 613 AD cases & $\begin{array}{l}\text { Vitamin E } \\
\text { ( } \alpha \text {-tocopherol) }\end{array}$ & $\begin{array}{l}2000 \text { IU daily } \\
\text { Oral }\end{array}$ & 2 & $\begin{array}{l}\text { ADCS } \\
\text { MMSE ADAS-cog } \\
\text { Caregiver Activity Survey }\end{array}$ & $\begin{array}{l}\text { Slowed functional decline } \\
(p=0.03)\end{array}$ \\
\hline $\begin{array}{l}\text { Kryscio et al. } \\
\text { (2017) }\end{array}$ & 7,540 cognitively normal & Vitamin $\mathrm{E}$ & $\begin{array}{l}400 \text { IU daily } \\
\text { Oral }\end{array}$ & 6 & $\begin{array}{l}\text { Memory Impairment Screen } \\
\text { Consortium to Establish a Registry } \\
\text { in Alzheimer's Disease }\end{array}$ & No significant cognitive benefits. \\
\hline
\end{tabular}


import of vitamin E. Differential responses of $\mathrm{AD}$ patients to vitamin E supplementation has led to stratification of individuals into respondents and non-respondents in one study (Lloret et al., 2009). Vitamin E effectively lowered oxidative stress and maintained cognitive status in respondents. Surprisingly, non-respondents experienced a sharp decline in cognition, to levels even lower than patients receiving a placebo (Lloret et al., 2009). Further investigations are required to successfully exploit vitamin E supplementation.

\section{$\mathrm{N}$-Acetylcysteine}

GSH is diminished in the hippocampus and frontal cortex in $\mathrm{AD}$ (Mandal et al., 2015), while lower plasma GSH is associated with severe cognitive impairment (McCaddon et al., 2003). Restoration of brain GSH with oral supplementation is ineffective as GSH rapidly hydrolyzes and insufficiently BBB-penetrant (Witschi et al., 1992). Similarly, L-cysteine (rate-limiting substrate for GSH synthesis) is inadequate due to extensive metabolism (Borgström and Kågedal, 1990). However, N-acetylcysteine, a precursor of L-cysteine, can efficaciously cross the $\mathrm{BBB}$ into the brain (Tardiolo et al., 2018). N-acetylcysteine mediates restoration of brain GSH levels and GPX4 activity in an AD mouse model, counteracting lipid peroxidation (Pocernich et al., 2000; Fu et al., 2006; Hsiao et al., 2012). A small trial showed 6-months
$\mathrm{N}$-acetylcysteine treatment did not improve Mini-Mental State Examination (MMSE) scores or daily living (Adair et al., 2001). Midpoint evaluation did show a trend towards a beneficial effect on the MMSE score though $(p=0.056)$, particularly on the letter fluency task (Table 3). N-acetylcysteine therapy may be more robust by increasing bioavailability, e.g., by using $\mathrm{N}$-acetylcysteine amide (Hara et al., 2017). This $\mathrm{N}$-acetylcysteine derivative has augmented permeability through cellular and mitochondrial membranes, as shown in the PD mouse model (Bahat-Stroomza et al., 2005). Interestingly, $\mathrm{MCI}$ and $\mathrm{AD}$ subjects supplemented with combined $\mathrm{N}$-acetylcysteine, $\alpha$-tocopherol, folate, vitamin B12, methionine, acetyl-L-carnitine demonstrated either stable or improved cognitive performance and mood/behavior (Remington et al., 2015a,b, 2016).

\section{Selenium}

Selenium is decreased in the hippocampal, temporal, and cortical regions in $\mathrm{AD}$, consistent with attenuated antioxidant capacity and augmented oxidative stress (Varikasuvu et al., 2019). Selenium, as selenocysteine, is essential for GPX4 synthesis. Six-months of consumption of Brazil nuts (high selenium) by MCI subjects replenished selenium levels (Table 4), improving verbal fluency and constructional praxis (Cardoso et al., 2016). Sodium selenate (over 24-weeks) lessened brain deterioration as

TABLE 3 | Clinical trials involving N-acetylcysteine in Alzheimer's disease (AD) and mild-cognitive impairment (MCI).

\begin{tabular}{|c|c|c|c|c|c|c|}
\hline Study & $\begin{array}{l}\text { Study } \\
\text { population }\end{array}$ & Treatment & Dose & $\begin{array}{l}\text { Duration } \\
\text { (years) }\end{array}$ & Outcome measures & Results \\
\hline $\begin{array}{l}\text { Adair et al. } \\
(2001)\end{array}$ & 47 AD cases & N-Acetylcysteine (NAC) & $\begin{array}{l}50 \mathrm{mg} / \mathrm{kg} \text { daily } \\
\text { Oral }\end{array}$ & 0.5 & $\begin{array}{l}\text { Mini-mental state examination } \\
\text { (MMSE) } \\
\text { Activities of daily living (ADL) } \\
\text { Boston naming test } \\
\text { Gesture to command } \\
\text { Wechsler memory scale figure } \\
\text { reproduction (immediate) } \\
\text { Hopkins verbal learning test recall } \\
\text { (immediate) and recognition } \\
\text { Letter and category fluency } \\
\text { Judgement of line orientation }\end{array}$ & $\begin{array}{l}\text { Significantly improved performance } \\
\text { on letter fluency }(p=0.008) \text {. } \\
\text { A trend of improved MMSE } \\
(p=0.056) .\end{array}$ \\
\hline $\begin{array}{l}\text { Remington } \\
\text { et al. (2015a) }\end{array}$ & 106 AD cases & $\begin{array}{l}\text { NAC } \\
\text { Folate } \\
\text { Alpha-tocopherol } \\
\text { B12 } \\
\text { S-Adenosyl methionine } \\
\text { (SAM) } \\
\text { Acetyl-L-carnitine }\end{array}$ & $\begin{array}{l}600 \mathrm{mg} \\
400 \mu \mathrm{g} \\
30 \mathrm{IU} \\
6 \mu \mathrm{g} \\
400 \mathrm{mg} \\
500 \mathrm{mg} \text {, twice daily } \\
\text { Oral }\end{array}$ & 1 & $\begin{array}{l}\text { Clox- } 1 \text { and the age- and } \\
\text { education-adjusted (AEMSS) } \\
\text { Dementia Rating Scale (DRS) } \\
\text { Behavioral and psychological } \\
\text { symptoms of dementia (BPSD) } \\
\text { Neuropsychiatry inventory (NPI) } \\
\text { ADL }\end{array}$ & $\begin{array}{l}\text { Improved cognitive performance } \\
(p<0.008)\end{array}$ \\
\hline $\begin{array}{l}\text { Remington } \\
\text { et al. (2015b) }\end{array}$ & $34 \mathrm{MCl}$ cases & $\begin{array}{l}\text { NAC } \\
\text { Folate } \\
\text { Alpha-tocopherol } \\
\text { B12 } \\
\text { SAM } \\
\text { Acetyl-L-carnitine }\end{array}$ & $\begin{array}{l}600 \mathrm{mg} \\
400 \mu \mathrm{g} \\
30 \mathrm{IU} \\
6 \mu \mathrm{g} \\
400 \mathrm{mg} \\
500 \mathrm{mg} \text {, twice daily } \\
\text { Oral }\end{array}$ & 1 & $\begin{array}{l}\text { AEMSS } \\
\text { Dementia Rating Scale (DRS) }\end{array}$ & $\begin{array}{l}\text { Improved cognitive performance } \\
(p<0.05)\end{array}$ \\
\hline $\begin{array}{l}\text { Remington } \\
\text { et al. (2016) }\end{array}$ & 24 AD cases & $\begin{array}{l}\text { NAC } \\
\text { Folate } \\
\text { Alpha-tocopherol } \\
\text { B12 } \\
\text { SAM } \\
\text { Acetyl-L-carnitine }\end{array}$ & $\begin{array}{l}600 \mathrm{mg} \\
400 \mu \mathrm{g} \\
30 \mathrm{IU} \\
6 \mu \mathrm{g} \\
400 \mathrm{mg} \\
500 \mathrm{mg} \text {, twice daily } \\
\text { Oral }\end{array}$ & 1 & $\begin{array}{l}\text { AEMSS } \\
\text { DRS } \\
\text { BPSD } \\
\text { NPI } \\
\text { ADL }\end{array}$ & $\begin{array}{l}\text { No significant improvements or } \\
\text { decline observed. }\end{array}$ \\
\hline
\end{tabular}


TABLE 4 | Clinical trials involving Selenium in Alzheimer's disease (AD) and mild-cognitive impairment (MCI).

\begin{tabular}{|c|c|c|c|c|c|c|}
\hline Study & $\begin{array}{l}\text { Study } \\
\text { population }\end{array}$ & Treatment & Dose & $\begin{array}{l}\text { Duration } \\
\text { (years) }\end{array}$ & Outcome measures & Results \\
\hline $\begin{array}{l}\text { Cardoso et al. } \\
\text { (2016) }\end{array}$ & $31 \mathrm{MCl}$ cases & $\begin{array}{l}\text { Selenium (from Brazilian } \\
\text { nuts) }\end{array}$ & $\begin{array}{l}288.75 \mu \mathrm{g} \text { daily } \\
\text { Oral }\end{array}$ & 0.5 & $\begin{array}{l}\text { Consortium to Establish a Registry } \\
\text { in Alzheimer's Disease } \\
\text { Selenium status } \\
\text { Erythrocyte glutathione peroxidase } \\
\text { (GPX4) activity } \\
\text { Oxygen radical absorbance } \\
\text { capacity (ORAC) } \\
\text { Plasma malondialdehyde }\end{array}$ & $\begin{array}{l}\text { Improved verbal fluency }(p=0.007) \\
\text { and constructional praxis }(p=0.03) \\
\text { Increased blood selenium } \\
(p<0.001) \text { and GPX4 }(p=0.006) \text {. }\end{array}$ \\
\hline $\begin{array}{l}\text { Malpas et al. } \\
(2016)\end{array}$ & 40 AD cases & Selenate (sodium salt) & $\begin{array}{l}30 \text { mg daily } \\
\text { Oral }\end{array}$ & 2 & $\begin{array}{l}\text { Alzheimer's Disease Assessment } \\
\text { Scale cognitive subscale } \\
\text { (ADAS-Cog) } \\
\text { Mini-mental state examination } \\
\text { (MMSE) } \\
\text { Controlled oral word association } \\
\text { test (COWAT) } \\
\text { Category fluency test (CFT) } \\
\text { Cogstate computerized battery } \\
\text { Structural and diffusion-weighted } \\
\text { MRI } \\
\text { FDG-PET (glucose metabolism) } \\
\text { Biomarker analysis ( } \beta \text {-amyloid, total } \\
\text { and phosphorylated tau) }\end{array}$ & $\begin{array}{l}\text { Less deterioration observed on the } \\
\text { diffusion-weighted MRI ( } p<0.05) \text {. } \\
\text { Mild pre-syncope (1) or dropped } \\
\text { out of the study due to skin rash } \\
\text { and nail changes (2). }\end{array}$ \\
\hline $\begin{array}{l}\text { Cardoso et al. } \\
\text { (2019) }\end{array}$ & 40 AD cases & Selenate (sodium salt) & $\begin{array}{l}30 \text { mg daily } \\
\text { Oral }\end{array}$ & 0.5 & $\begin{array}{l}\text { ADAS-Cog } \\
\text { MMSE } \\
\text { COWAT } \\
\text { CFT } \\
\text { Cogstate computerized battery } \\
\text { Total selenium serum and CSF } \\
\text { concentrations }\end{array}$ & $\begin{array}{l}\text { Responders to treatment showed } \\
\text { increased serum }(p=0.007) \text { and } \\
\text { CSF selenium ( } p=0.03) \text {, and } \\
\text { showed no significant cognitive } \\
\text { decline. }\end{array}$ \\
\hline
\end{tabular}

assessed by diffusion tensor MRI, but did not impact cognitive performance (Malpas et al., 2016). Interestingly, on stratification into responders and non-responders based on the elevation of CSF levels, MMSE scores did not deteriorate in responders compared to non-responders (Cardoso et al., 2019). Conversely, in the PREADVISE clinical trial, selenomethionine did not reduce the incidence of dementia in cognitively healthy males, aged $>60$ years (Kryscio et al., 2017), but subjects were not stratified according to their CSF selenium status. Furthermore, the incidence of dementia on follow-up was low, possibly attributable to selection bias as participants were more educated than the general population and exhibited greater cognitive reserve. The absence of biomarkers for target engagement of supplements renders the translation of basic scientific findings into robust prevention trials difficult.

\section{TARGETING FERROPTOSIS-THE FUTURE OF AD?}

Despite rigorous clinical testing of pharmaceutical agents in $\mathrm{AD}$, only four have been licensed: anticholinesterase inhibitors (donepezil, galantamine, and rivastigmine) that increase synaptic acetylcholine to aid learning and memory; and an NMDA-receptor antagonist (memantine). Interestingly, the neuroprotective effects of memantine were reported to be mediated by enhancing the astroglial system $\mathrm{X}_{\mathrm{c}}^{-}$activity (Okada et al., 2019). The increased glutamate export appears to activate inhibitory metabotropic glutamate receptors to attenuate cognitive impairment from hyperactivation of thalamocortical glutamatergic transmission (Okada et al., 2019). However, the beneficial effects may result from inhibition of ferroptosis arising from the concomitant increased intracellular cystine/GSH (see above).

Animals fed with excess iron demonstrate increased lipid peroxidation, BBB breakdown, altered mitochondrial dynamics, $\beta$-amyloid deposition, tau hyperphosphorylation, and loss of dendritic spine density-reminiscent of $\mathrm{AD}$ pathology (Sripetchwandee et al., 2014, 2016). Combinatorial therapy with deferiprone and $\mathrm{N}$-acetylcysteine, exerted greater neuroprotection from iron-induced toxicity than monotherapy, including restored dendritic spine density, mitochondrial balance and ameliorated AD pathology (Sripetchwandee et al., 2014, 2016). Furthermore, the concept of targeting ferroptosis is supported by evidence of iron dyshomeostasis, altered system $\mathrm{X}_{\mathrm{c}}^{-}$dynamics (diminished GSH/GPX4 activity) and enhanced lipid peroxidation in $\mathrm{AD}$ (Ashraf et al., 2020; Figure 1).

The challenges of conclusively identifying ferroptosis in vivo and post-mortem brain samples are hindered by the lack of specific markers for cells undergoing ferroptosis. It is important to state that different cell death patterns happen in parallel contributing to disease pathology. For example, it is known that ferroptosis and other types of cell deaths (necroptosis and apoptosis) occur concurrently following ischemic and traumatic brain injury (Zille et al., 2017; Magtanong and Dixon, 2018). The 


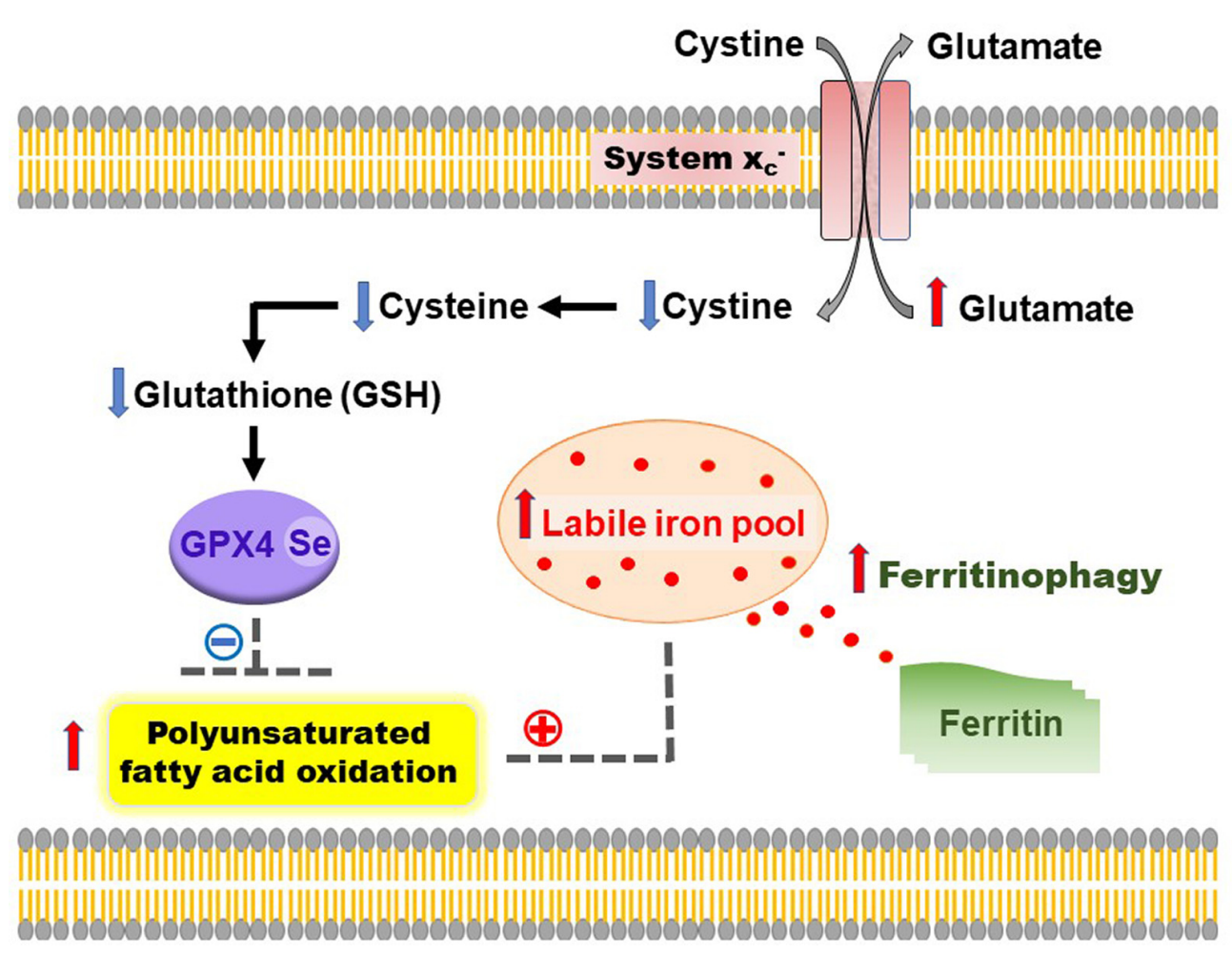

FIGURE 1 | Overview of ferroptosis in Alzheimer's disease (AD). During the process of ferroptosis, autophagy of ferritin (ferritinophagy) contributes to an increased labile iron pool, leading to elevated lipid peroxidation and oxidation of polyunsaturated fatty acids. This is aggravated by inhibition of the cystine/glutamate antiporter (system $\mathrm{X}_{\mathrm{c}}^{-}$), rendering the cell-deficient of cysteine, which has a domino effect of lowering glutathione (GSH) levels and impairs the activity of a selenium-dependent lipid repair enzyme, glutathione peroxidase-4 (GPX4) - a master regulator of ferroptosis. Combinatorial therapies targeted at maintaining iron homeostasis and restoring GSH levels/GPX4 will help to lower iron-induced lipid peroxidation and inhibit ferroptosis in AD.

detection of markers that may indicate the presence of ferroptosis does not preclude the presence of other types of cell death. There are no established biomarkers that can detect ferroptosis in humans although different lines of evidence implicate a role for ferroptosis in AD. Development of a "ferroptosis-specific" antibody would be very informative in examining the effects of ferroptosis in multiple contexts including post-mortem samples and in vivo experiments.

Unlike clinical trials targeting $\beta$-amyloid, ferroptosismodulating clinical trials have been exploratory and dose optimization still required as well as replication on a larger scale (Nikseresht et al., 2019). Concomitant identification of biomarkers for ferroptosis is also required for more rigorous inclusion/exclusion into clinical trials and robust evaluation/formal testing of novel therapies targeting the ferroptotic cascade. Many outstanding questions remain though-what are the individual contributions from microglia, astrocytes, oligodendrocytes, and neurons to ferroptosis? Is iron and its proteins differentially expressed in glia and neurons? What is the role of other transition metals, zinc, and copper, in ferroptosis and possible interactions with iron?

Mitochondria is the major site of energy production but coincidently for iron metabolism also. Mitochondrial dysfunction is thought to occur early in $\mathrm{AD}$ pathogenesis
(Horowitz and Greenamyre, 2010). Damaged mitochondria are cleared by mitophagy to maintain mitochondrial homeostasis and shown to inhibit AD pathology in animal AD models (Fang et al., 2019). Furthermore, mitochondria depletion by Parkinmediated mitophagy inhibited cysteine-deprivation induced ferroptosis (Basit et al., 2017). How iron metabolism relates to mitophagy, is mitophagy related to ferroptosis or a distinct phenomenon in $\mathrm{AD}$ remains to be addressed.

Neuroinflammation is a major characteristic of $\mathrm{AD}$ and represents a useful therapeutic target (Ong and Farooqui, 2005). Although crosstalk exists between neuroinflammation and iron metabolism (Urrutia et al., 2014), the relationship and contribution of ferroptosis to inflammation remains to be addressed.

Our discussion so far has focused on the cellular LIP, but $95 \%$ of functional iron in the body is in heme. Heme from hemoglobin breakdown can be a redox-active iron source, to induce/enhance lipid peroxidation and ferroptosis (NaveenKumar et al., 2018). AD is characterized by perturbed BBB permeability (Sripetchwandee et al., 2014, 2016). It will be pivotal to delineate the relationship between plasma and brain heme/iron homeostasis, and peripheral contributions to ferroptosis at different stages of the disease. Such knowledge will potentially identify peripheral ferroptosis biomarkers needed for future 
anti-ferroptosis trials to formally test ferroptosis contributions to $\mathrm{AD}$ and possibly other neurodegenerative diseases.

\section{CONCLUSION}

Iron dyshomeostasis, impaired antioxidant defense, and lipid peroxidation are features of ferroptosis that could offer successful therapeutic targets in $\mathrm{AD}$. Research on ferroptosis in the context of $\mathrm{AD}$ and other neurodegenerative diseases is still in its infancy. Exploration of the mechanism of ferroptosis and its role in $\mathrm{AD}$ has the potential to propose novel therapeutic approaches for, hitherto absent, highly effective treatments against $\mathrm{AD}$ and possibly, other neurodegenerative diseases.

\section{REFERENCES}

Adair, J. C., Knoefel, J. E., and Morgan, N. (2001). Controlled trial of $\mathrm{N}$-acetylcysteine for patients with probable Alzheimer's disease. Neurology 57, 1515-1517. doi: 10.1212/wnl.57.8.1515

Alzheimer's Disease International. (2019). World Alzheimer Report 2019: Attitudes to dementia. London: Alzheimer's Disease International.

Andrieu, S., Guyonnet, S., Coley, N., Cantet, C., Bonnefoy, M., Bordes, S., et al. (2017). Effect of long-term $\omega 3$ polyunsaturated fatty acid supplementation with or without multidomain intervention on cognitive function in elderly adults with memory complaints (MAPT): a randomised, placebo-controlled trial. Lancet Neurol. 16, 377-389. doi: 10.1016/S1474-4422(17)30040-6

Ashraf, A., Clark, M., and So, P. W. (2018). The aging of iron man. Front. Aging Neurosci. 10:65. doi: 10.3389/fnagi.2018.00065

Ashraf, A., Jeandriens, J., Parkes, H. G., and So, P. W. (2020). Iron dyshomeostasis, lipid peroxidation and perturbed expression of cystine/glutamate antiporter in Alzheimer's disease: evidence of ferroptosis. Redox. Biol. 32:101494. doi: 10.1016/j.redox.2020.101494

Ashraf, A., Stosnach, H., Parkes, H. G., Hye, A., Powell, J., So, P. W., et al. (2019). Pattern of altered plasma elemental phosphorus, calcium, zinc and iron in Alzheimer's disease. Sci. Rep. 9:3147. doi: 10.1038/s41598-01837431-8

Ayton, S., Faux, N. G., Bush, A. I., and Alzheimer's Disease Neuroimaging, I. (2015). Ferritin levels in the cerebrospinal fluid predict Alzheimer's disease outcomes and are regulated by APOE. Nat. Commun. 6:6760. doi: $10.1038 /$ ncomms7760

Bahat-Stroomza, M., Gilgun-Sherki, Y., Offen, D., Panet, H., Saada, A., KroolGalron, N., et al. (2005). A novel thiol antioxidant that crosses the blood brain barrier protects dopaminergic neurons in experimental models of Parkinson's disease. Eur. J. Neurosci. 21, 637-646. doi: 10.1111/j.1460-9568.2005.03889.x

Basambombo, L. L., Carmichael, P. H., Cote, S., and Laurin, D. (2017). Use of vitamin $\mathrm{E}$ and $\mathrm{C}$ supplements for the prevention of cognitive decline. Ann. Pharmacother. 51, 118-124. doi: 10.1177/1060028016673072

Basit, F., van Oppen, L. M., Schockel, L., Bossenbroek, H. M., van Emst-de Vries, S. E., Hermeling, J. C., et al. (2017). Mitochondrial complex I inhibition triggers a mitophagy-dependent ROS increase leading to necroptosis and ferroptosis in melanoma cells. Cell Death Dis. 8:e2716. doi: 10.1038/cddis. 2017.133

Borgna-Pignatti, C., and Marsella, M. (2015). Iron chelation in thalassemia major. Clin. Ther. 37, 2866-2877. doi: 10.1016/j.clinthera.2015.10.001

Borgström, L., and Kågedal, B. (1990). Dose dependent pharmacokinetics of $\mathrm{N}$-acetylcysteine after oral dosing to man. Biopharm. Drug Dispos. 11, 131-136. doi: 10.1002/bdd.2510110205

Brigelius-Flohé, R. (2009). Vitamin E: the shrew waiting to be tamed. Free Radic. Biol. Med. 46, 543-554. doi: 10.1016/j.freeradbiomed.2008.12.007

Cardoso, B. R., Roberts, B. R., Malpas, C. B., Vivash, L., Genc, S., Saling, M. M., et al. (2019). Supranutritional sodium selenate supplementation delivers selenium to the central nervous system: results from a randomized controlled pilot trial in Alzheimer's disease. Neurotherapeutics 16, 192-202. doi: 10.1007/s13311-018-0662-z

\section{AUTHOR CONTRIBUTIONS}

AA conceived and designed the manuscript. P-WS reviewed and approved the manuscript and obtained the funding.

\section{FUNDING}

This work was supported by an industrial Ph.D. studentship for AA (as part of the London Interdisciplinary Doctoral Program) funded by the Biotechnology and Biological Sciences Research Council (BBSRC), King's College London and Perspectum Diagnostics Limited.

Cardoso, B., Apolinario, D., da Silva Bandeira, V., Busse, A. L., Magaldi, R. M., Jacob-Filho, W., et al. (2016). Effects of Brazil nut consumption on selenium status and cognitive performance in older adults with mild cognitive impairment: a randomized controlled pilot trial. Eur. J. Nutr. 55, 107-116. doi: 10.1007/s00394-014-0829-2

Crapper McLachlan, D. R., Dalton, A. J., Kruck, T. P., Bell, M. Y., Smith, W. L., Kalow, W., et al. (1991). Intramuscular desferrioxamine in patients with Alzheimer's disease. Lancet 337, 1304-1308. doi: 10.1016/0140-6736(91) 92978-b

David, D. C., Hauptmann, S., Scherping, I., Schuessel, K., Keil, U., Rizzu, P., et al. (2005). Proteomic and functional analyses reveal a mitochondrial dysfunction in P301L tau transgenic mice. J. Biol. Chem. 280, 23802-23814. doi: 10.1074/jbc. M500356200.

De Domenico, I., Ward, D. M., di Patti, M. C., Jeong, S. Y., David, S., Musci, G., et al. (2007). Ferroxidase activity is required for the stability of cell surface ferroportin in cells expressing GPI-ceruloplasmin. EMBO J. 26, 2823-2831. doi: 10.1038/sj.emboj.7601735

Devi, L., Prabhu, B. M., Galati, D. F., Avadhani, N. G., and Anandatheerthavarada, H. K. (2006). Accumulation of amyloid precursor protein in the mitochondrial import channels of human Alzheimer's disease brain is associated with mitochondrial dysfunction. J. Neurosci. 26, 9057-9068. doi: 10.1523/JNEUROSCI.1469-06.2006

Devore, E. E., Grodstein, F., van Rooij, F. J., Hofman, A., Stampfer, M. J., Witteman, J. C., et al. (2010). Dietary antioxidants and long-term risk of dementia. Arch. Neurol. 67, 819-825. doi: 10.1001/archneurol.2010.144

Devos, D., Moreau, C., Devedjian, J. C., Kluza, J., Petrault, M., Laloux, C., et al. (2014). Targeting chelatable iron as a therapeutic modality in Parkinson's disease. Antioxid. Redox. Signal. 21, 195-210. doi: 10.1089/ars.2013.559

de Wilde, M. C., Vellas, B., Girault, E., Yavuz, A. C., and Sijben, J. W. (2017) Lower brain and blood nutrient status in Alzheimer's disease: results from meta-analyses. Alzheimers Dement. 3, 416-431. doi: 10.1016/j.trci.2017.06.002

Dixon, S. J., Lemberg, K. M., Lamprecht, M. R., Skouta, R., Zaitsev, E. M., Gleason, C. E., et al. (2012). Ferroptosis: an iron-dependent form of nonapoptotic cell death. Cell 149, 1060-1072. doi: 10.1016/j.cell.2012.03.042

Doll, S., Proneth, B., Tyurina, Y. Y., Panzilius, E., Kobayashi, S., Ingold, I., et al. (2017). ACSL4 dictates ferroptosis sensitivity by shaping cellular lipid composition. Nat. Chem. Biol. 13, 91-98. doi: 10.1038/nchembio.2239

Dysken, M. W., Sano, M., Asthana, S., Vertrees, J. E., Pallaki, M., Llorente, M., et al. (2014). Effect of vitamin $\mathrm{E}$ and memantine on functional decline in Alzheimer disease: the TEAM-AD VA cooperative randomized trial. JAMA 311, 33-44. doi: 10.1001/jama.2013.282834

Engelhart, M. J., Geerlings, M. I., Ruitenberg, A., van Swieten, J. C., Hofman, A., Witteman, J. C., et al. (2002). Dietary intake of antioxidants and risk of Alzheimer disease. JAMA 287, 3223-3229. doi: 10.1001/jama.287.24.3223

Fang, E. F., Hou, Y., Palikaras, K., Adriaanse, B. A., Kerr, J. S., Yang, B., et al. (2019). Mitophagy inhibits amyloid- $\beta$ and tau pathology and reverses cognitive deficits in models of Alzheimer's disease. Nat. Neurosci. 22, 401-412. doi: 10.1038/s41593-018-0332-9

Fine, J. M., Baillargeon, A. M., Renner, D. B., Hoerster, N. S., Tokarev, J., Colton, S., et al. (2012). Intranasal deferoxamine improves performance in 
radial arm water maze, stabilizes HIF- $1 \alpha$ and phosphorylates GSK3 $\beta$ in P301L tau transgenic mice. Exp. Brain Res. 219, 381-390. doi: 10.1007/s00221-0123101-0

Fine, J. M., Renner, D. B., Forsberg, A. C., Cameron, R. A., Galick, B. T., Le, C., et al. (2015). Intranasal deferoxamine engages multiple pathways to decrease memory loss in the APP/PS1 model of amyloid accumulation. Neurosci. Lett. 584, 362-367. doi: 10.1016/j.neulet.2014.11.013

Fu, A. L., Dong, Z. H., and Sun, M. J. (2006). Protective effect of N-acetyl-Lcysteine on amyloid $\beta$-peptide-induced learning and memory deficits in mice. Brain Res. 1109, 201-206. doi: 10.1016/j.brainres.2006.06.042

Gao, M., Monian, P., Pan, Q., Zhang, W., Xiang, J., and Jiang, X. (2016). Ferroptosis is an autophagic cell death process. Cell Res. 26, 1021-1032. doi: 10.1038/cr.2016.95

Gao, M., Monian, P., Quadri, N., Ramasamy, R., and Jiang, X. (2015). Glutaminolysis and transferrin regulate ferroptosis. Mol. Cell 59, 298-308. doi: 10.1016/j.molcel.2015.06.011

Gao, M., Yi, J., Zhu, J., Minikes, A. M., Monian, P., Thompson, C. B., et al. (2019). Role of mitochondria in ferroptosis. Mol. Cell 73, 354-363. e353. doi: 10.1016/j. molcel.2018.10.042

Goodman, L. (1953). Alzheimer's disease; a clinico-pathologic analysis of twentythree cases with a theory on pathogenesis. J. Nerv. Ment. Dis. 118, 97-130. doi: 10.1097/00005053-195308000-00001

Gray, S. L., Anderson, M. L., Crane, P. K., Breitner, J. C., McCormick, W., Bowen, J. D., et al. (2008). Antioxidant vitamin supplement use and risk of dementia or Alzheimer's disease in older adults. J. Am. Geriatr. Soc. 56, 291-295. doi: 10.1111/j.1532-5415.2007.01531.x

Guo, C., Wang, P., Zhong, M. L., Wang, T., Huang, X. S., Li, J. Y., et al. (2013a). Deferoxamine inhibits iron induced hippocampal tau phosphorylation in the Alzheimer transgenic mouse brain. Neurochem. Int. 62, 165-172. doi: 10.1016/j. neuint.2012.12.005

Guo, C., Wang, T., Zheng, W., Shan, Z. Y., Teng, W. P., and Wang, Z. Y. (2013b). Intranasal deferoxamine reverses iron-induced memory deficits and inhibits amyloidogenic APP processing in a transgenic mouse model of Alzheimer's disease. Neurobiol. Aging 34, 562-575. doi: 10.1016/j.neurobiolaging.2012. 05.009

Hambright, W. S., Fonseca, R. S., Chen, L., Na, R., and Ran, Q. (2017). Ablation of ferroptosis regulator glutathione peroxidase 4 in forebrain neurons promotes cognitive impairment and neurodegeneration. Redox. Biol. 12, 8-17. doi: 10.1016/j.redox.2017.01.021

Hansson Petersen, C. A., Alikhani, N., Behbahani, H., Wiehager, B., Pavlov, P. F., Alafuzoff, I., et al. (2008). The amyloid $\beta$-peptide is imported into mitochondria via the TOM import machinery and localized to mitochondrial cristae. Proc. Natl. Acad. Sci. U S A 105, 13145-13150. doi: 10.1073/pnas.080 6192105

Hara, Y., McKeehan, N., Dacks, P. A., and Fillit, H. M. (2017). Evaluation of the neuroprotective potential of $\mathrm{N}$-acetylcysteine for prevention and treatment of cognitive aging and dementia. J. Prev. Alzheimers Dis. 4, 201-206. doi: 10.14283/jpad.2017.22

Harrison, P. M., and Arosio, P. (1996). The ferritins: molecular properties, iron storage function and cellular regulation. Biochim. Biophys. Acta 1275, 161-203. doi: 10.1016/0005-2728(96)00022-9

Heneka, M. T., Fink, A., and Doblhammer, G. (2015). Effect of pioglitazone medication on the incidence of dementia. Ann. Neurol. 78, 284-294. doi: 10.1002/ana.24439

Horowitz, M. P., and Greenamyre, J. T. (2010). Mitochondrial iron metabolism and its role in neurodegeneration. J. Alzheimers Dis. 2, S551-S568. doi: 10.3233/JAD-2010-100354

Hou, W., Xie, Y., Song, X., Sun, X., Lotze, M. T., Zeh, H. J. III., et al. (2016). Autophagy promotes ferroptosis by degradation of ferritin. Autophagy 12, 1425-1428. doi: 10.1080/15548627.2016.1187366

Hsiao, Y. H., Kuo, J. R., Chen, S. H., and Gean, P. W. (2012). Amelioration of social isolation-triggered onset of early Alzheimer's disease-related cognitive deficit by $\mathrm{N}$-acetylcysteine in a transgenic mouse model. Neurobiol. Dis. 45, 1111-1120. doi: 10.1016/j.nbd.2011.12.031

Jeong, S. Y., Rathore, K. I., Schulz, K., Ponka, P., Arosio, P., and David, S. (2009). Dysregulation of iron homeostasis in the CNS contributes to disease progression in a mouse model of amyotrophic lateral sclerosis. J. Neurosci. 29, 610-619. doi: 10.1523/JNEUROSCI.5443-08.2009
Joffre, C., Rey, C., and Laye, S. (2019). N-3 polyunsaturated fatty acids and the resolution of neuroinflammation. Front. Pharmacol. 10:1022. doi: 10.3389/fphar.2019.01022

Joppe, K., Roser, A. E., Maass, F., and Lingor, P. (2019). The contribution of iron to protein aggregation disorders in the central nervous system. Front. Neurosci. 13:15. doi: 10.3389/fnins.2019.00015

Kagerer, S. M., van Bergen, J. M. G., Li, X., Quevenco, F. C., Gietl, A. F., Studer, S., et al. (2020). APOE4 moderates effects of cortical iron on synchronized default mode network activity in cognitively healthy old-aged adults. Alzheimers Dement. 12:e12002. doi: 10.1002/dad2.12002

Kakhlon, O., and Cabantchik, Z. I. (2002). The labile iron pool: characterization, measurement and participation in cellular processes(1). Free Radic. Biol. Med. 33, 1037-1046. doi: 10.1016/s0891-5849(02)01006-7

Kruszewski, M. (2003). Labile iron pool: the main determinant of cellular response to oxidative stress. Mutat. Res. 531, 81-92. doi: 10.1016/j.mrfmmm.2003. 08.004

Kryscio, R. J., Abner, E. L., Caban-Holt, A., Lovell, M., Goodman, P., Darke, A. K., et al. (2017). Association of antioxidant supplement use and dementia in the prevention of Alzheimer's disease by vitamin $\mathrm{E}$ and selenium trial (PREADViSE). JAMA Neurol. 74, 567-573. doi: 10.1001/jamaneurol.2016.5778

Laitinen, M. H., Ngandu, T., Rovio, S., Helkala, E. L., Uusitalo, U., Viitanen, M., et al. (2006). Fat intake at midlife and risk of dementia and Alzheimer's disease: a population-based study. Dement. Geriatr. Cogn. Disord. 22, 99-107. doi: $10.1159 / 000093478$

Lloret, A., Badia, M. C., Mora, N. J., Pallardo, F. V., Alonso, M. D., and Vina, J. (2009). Vitamin E paradox in Alzheimer's disease: it does not prevent loss of cognition and may even be detrimental. J. Alzheimers Dis. 17, 143-149. doi: 10.3233/jad-2009-1033

Luchsinger, J. A., Tang, M. X., Shea, S., and Mayeux, R. (2003). Antioxidant vitamin intake and risk of Alzheimer disease. Arch. Neurol. 60, 203-208. doi: 10.1001/archneur.60.2.203

Magtanong, L., and Dixon, S. J. (2018). Ferroptosis and brain injury. Dev. Neurosci. 40, 382-395. doi: 10.1159/000496922

Maguire, J. J., Wilson, D. S., and Packer, L. (1989). Mitochondrial electron transport-linked tocopheroxyl radical reduction. J. Biol. Chem. 264, $21462-21465$.

Malpas, C. B., Vivash, L., Genc, S., Saling, M. M., Desmond, P., Steward, C., et al. (2016). A phase IIa randomized control trial of VEL015 (Sodium Selenate) in mild-moderate Alzheimer's disease. J. Alzheimers Dis. 54, 223-232. doi: 10.3233/JAD-160544

Mandal, P. K., Saharan, S., Tripathi, M., and Murari, G. (2015). Brain glutathione levels-a novel biomarker for mild cognitive impairment and Alzheimer's disease. Biol. Psychiatry 78, 702-710. doi: 10.1016/j.biopsych.2015.04.005

Martin-Bastida, A., Ward, R. J., Newbould, R., Piccini, P., Sharp, D., Kabba, C., et al. (2017). Brain iron chelation by deferiprone in a phase 2 randomised double-blinded placebo controlled clinical trial in Parkinson's disease. Sci. Rep. 7:1398. doi: 10.1038/s41598-017-01402-2

Masaki, K. H., Losonczy, K. G., Izmirlian, G., Foley, D. J., Ross, G. W., Petrovitch, H., et al. (2000). Association of vitamin E and C supplement use with cognitive function and dementia in elderly men. Neurology 54, 1265-1272. doi: $10.1212 /$ wnl.54.6.1265

McCaddon, A., Hudson, P., Hill, D., Barber, J., Lloyd, A., Davies, G., et al. (2003). Alzheimer's disease and total plasma aminothiols. Biol. Psychiatry 53, 254-260. doi: 10.1016/s0006-3223(02)01451-8

NaveenKumar, S. K., SharathBabu, B. N., Hemshekhar, M., Kemparaju, K., Girish, K. S., and Mugesh, G. (2018). The role of reactive oxygen species and ferroptosis in heme-mediated activation of human platelets. ACS Chem. Biol. 13, 1996-2002. doi: 10.1021/acschembio.8b00458

Nikseresht, S., Bush, A. I., and Ayton, S. (2019). Treating Alzheimer's disease by targeting iron. Br. J. Pharmacol. 176, 3622-3635. doi: 10.1111/bph. 14567

Okada, M., Fukuyama, K., Kawano, Y., Shiroyama, T., and Ueda, Y. (2019). Memantine protects thalamocortical hyper-glutamatergic transmission induced by NMDA receptor antagonism via activation of system $\mathrm{xc}<\mathrm{sup} />$. Pharmacol. Res. Perspect. 7:e00457. doi: 10.1002/prp2.457

Ong, W. Y., and Farooqui, A. A. (2005). Iron, neuroinflammation and Alzheimer's disease. J. Alzheimers Dis. 8, 183-200; discussion 209-115. doi: 10.3233/jad2005-8211 
Petersen, R. C., Thomas, R. G., Grundman, M., Bennett, D., Doody, R., Ferris, S., et al. (2005). Vitamin E and donepezil for the treatment of mild cognitive impairment. N. Engl. J. Med. 352, 2379-2388. doi: 10.1056/NEJMoa 050151

Petrat, F., de Groot, H., Sustmann, R., and Rauen, U. (2002). The chelatable iron pool in living cells: a methodically defined quantity. Biol. Chem. 383, 489-502. doi: 10.1515/BC.2002.051

Pocernich, C. B., La Fontaine, M., and Butterfield, D. A. (2000). In vivo glutathione elevation protects against hydroxyl free radical-induced protein oxidation in rat brain. Neurochem. Int. 36, 185-191. doi: 10.1016/s0197-0186(99) 00126-6

Remington, R., Bechtel, C., Larsen, D., Samar, A., Doshanjh, L., Fishman, P., et al. (2015a). A phase II randomized clinical trial of a nutritional formulation for cognition and mood in Alzheimer's disease. J. Alzheimers Dis. 45, 395-405. doi: $10.3233 /$ jad-142499

Remington, R., Lortie, J. J., Hoffmann, H., Page, R., Morrell, C., and Shea, T. B. (2015b). A nutritional formulation for cognitive performance in mild cognitive impairment: a placebo-controlled trial with an open-label extension. J. Alzheimers Dis. 48, 591-595. doi: 10.3233/JAD-150057

Remington, R., Bechtel, C., Larsen, D., Samar, A., Page, R., Morrell, C., et al. (2016). Maintenance of cognitive performance and mood for individuals with Alzheimer's disease following consumption of a nutraceutical formulation: a one-year, open-label study. J. Alzheimers Dis. 51, 991-995. doi: 10.3233/JAD151098

Rhein, V., Song, X., Wiesner, A., Ittner, L. M., Baysang, G., Meier, F., et al. (2009). Amyloid- $\beta$ and tau synergistically impair the oxidative phosphorylation system in triple transgenic Alzheimer's disease mice. Proc. Natl. Acad. Sci. U S A 106, 20057-20062. doi: 10.1073/pnas.0905529106

Robinson, J. L., Lee, E. B., Xie, S. X., Rennert, L., Suh, E., Bredenberg, C., et al. (2018). Neurodegenerative disease concomitant proteinopathies are prevalent, age-related and APOE4-associated. Brain 141, 2181-2193. doi: 10.1093/brain/awy146

Rottkamp, C. A., Raina, A. K., Zhu, X., Gaier, E., Bush, A. I., Atwood, C. S., et al. (2001). Redox-active iron mediates amyloid- $\beta$ toxicity. Free Radic. Biol. Med. 30, 447-450. doi: 10.1016/s0891-5849(00)00494-9

Sano, M., Ernesto, C., Thomas, R. G., Klauber, M. R., Schafer, K., Grundman, M., et al. (1997). A controlled trial of selegiline, $\alpha$-tocopherol, or both as treatment for Alzheimer's disease. The Alzheimer's disease cooperative study. N. Engl. J. Med. 336, 1216-1222. doi: 10.1056/NEJM1997042433 61704

Sayre, L. M., Perry, G., Harris, P. L., Liu, Y., Schubert, K. A., and Smith, M. A. (2000). in situ oxidative catalysis by neurofibrillary tangles and senile plaques in Alzheimer's disease: a central role for bound transition metals. J. Neurochem. 74, 270-279. doi: 10.1046/j.1471-4159.2000.0740270.x

Seiler, A., Schneider, M., Forster, H., Roth, S., Wirth, E. K., Culmsee, C., et al. (2008). Glutathione peroxidase 4 senses and translates oxidative stress into 12/15-lipoxygenase dependent- and AIF-mediated cell death. Cell Metab. 8, 237-248. doi: 10.1016/j.cmet.2008.07.005

Simonovitch, S., Schmukler, E., Masliah, E., Pinkas-Kramarski, R., and Michaelson, D. M. (2019). The effects of APOE4 on mitochondrial dynamics and proteins in vivo. J. Alzheimers Dis. 70, 861-875. doi: 10.3233/JAD190074

Sripetchwandee, J., Pipatpiboon, N., Chattipakorn, N., and Chattipakorn, S. (2014). Combined therapy of iron chelator and antioxidant completely restores brain dysfunction induced by iron toxicity. PLoS One 9:e85115. doi: 10.1371/journal.pone.0085115

Sripetchwandee, J., Wongjaikam, S., Krintratun, W., Chattipakorn, N., and Chattipakorn, S. C. (2016). A combination of an iron chelator with an antioxidant effectively diminishes the dendritic loss, tauhyperphosphorylation, amyloids- $\beta$ accumulation and brain mitochondrial dynamic disruption in rats with chronic iron-overload. Neuroscience 332, 191-202. doi: 10.1016/j.neuroscience.2016.07.003

Stocker, R. (2007). Vitamin E. Novartis Foundation Symposia 282, 77-87; discussion 87-92, 212-218. doi: 10.1002/9780470319444.ch6

Stockwell, B. R., Friedmann Angeli, J. P., Bayir, H., Bush, A. I., Conrad, M., Dixon, S. J., et al. (2017). Ferroptosis: a regulated cell death nexus linking metabolism, redox biology and disease. Cell 171, 273-285. doi: 10.1016/j.cell. 2017.09.021
Tardiolo, G., Bramanti, P., and Mazzon, E. (2018). Overview on the effects of n-acetylcysteine in neurodegenerative diseases. Molecules 23:3305. doi: 10.3390/molecules23123305

Urrutia, P. J., Mena, N. P., and Nunez, M. T. (2014). The interplay between iron accumulation, mitochondrial dysfunction and inflammation during the execution step of neurodegenerative disorders. Front. Pharmacol. 5:38. doi: 10.3389/fphar.2014.00038

Varikasuvu, S. R., Prasad, V. S., Kothapalli, J., and Manne, M. (2019). Brain selenium in Alzheimer's disease (BRAIN SEAD Study): a systematic review and meta-analysis. Biol. Trace Elem. Res. 189, 361-369. doi: 10.1007/s12011-0181492-x

Wang, P., Deng, J., Dong, J., Liu, J., Bigio, E. H., Mesulam, M., et al. (2019). TDP43 induces mitochondrial damage and activates the mitochondrial unfolded protein response. PLoS Genet. 15:e1007947. doi: 10.1371/journal.pgen. 1007947

Wang, W., Wang, L., Lu, J., Siedlak, S. L., Fujioka, H., Liang, J., et al. (2016). The inhibition of TDP-43 mitochondrial localization blocks its neuronal toxicity. Nat. Med. 22, 869-878. doi: 10.1038/nm.4130

Ward, R. J., Zucca, F. A., Duyn, J. H., Crichton, R. R., and Zecca, L. (2014). The role of iron in brain ageing and neurodegenerative disorders. Lancet Neurol. 13, 1045-1060. doi: 10.1016/s1474-4422(14) 70117-6

Witschi, A., Reddy, S., Stofer, B., and Lauterburg, B. H. (1992). The systemic availability of oral glutathione. Eur. J. Clin. Pharmacol. 43, 667-669. doi: 10.1007/bf02284971

Xiao, Y., Chen, X., Huang, S., Li, G., Mo, M., Zhang, L., et al. (2018). Iron promotes $\alpha$-synuclein aggregation and transmission by inhibiting TFEB-mediated autophagosome-lysosome fusion. J. Neurochem. 145, 34-50. doi: 10.1111/jnc. 14312

Yagoda, N., von Rechenberg, M., Zaganjor, E., Bauer, A. J., Yang, W. S., Fridman, D. J., et al. (2007). RAS-RAF-MEK-dependent oxidative cell death involving voltage-dependent anion channels. Nature 447, 864-868. doi: 10.1038/nature05859

Yang, W. S., Kim, K. J., Gaschler, M. M., Patel, M., Shchepinov, M. S., and Stockwell, B. R. (2016). Peroxidation of polyunsaturated fatty acids by lipoxygenases drives ferroptosis. Proc. Natl. Acad. Sci. U S A 113, E4966-4975. doi: 10.1073/pnas.1603244113

Yao, J., Irwin, R. W., Zhao, L., Nilsen, J., Hamilton, R. T., and Brinton, R. D. (2009). Mitochondrial bioenergetic deficit precedes Alzheimer's pathology in female mouse model of Alzheimer's disease. Proc. Natl. Acad. Sci. U S A 106, 14670-14675. doi: 10.1073/pnas.0903 563106

Yassine, H. N., Braskie, M. N., Mack, W. J., Castor, K. J., Fonteh, A. N., Schneider, L. S., et al. (2017). Association of docosahexaenoic acid supplementation with Alzheimer disease stage in apolipoprotein E\&4 carriers: a review. JAMA Neurol. 74, 339-347. doi: 10.1001/jamaneurol.2016.4899

Youdim, M. B. (2008). Brain iron deficiency and excess; cognitive impairment and neurodegeneration with involvement of striatum and hippocampus. Neurotox. Res. 14, 45-56. doi: 10.1007/BF03033574

Zandi, P. P., Anthony, J. C., Khachaturian, A. S., Stone, S. V., Gustafson, D., Tschanz, J. T., et al. (2004). Reduced risk of Alzheimer disease in users of antioxidant vitamin supplements: the cache county study. Arch. Neurol. 61, 82-88. doi: 10.1001/archneur.61.1.82

Zille, M., Karuppagounder, S. S., Chen, Y., Gough, P. J., Bertin, J., Finger, J., et al. (2017). Neuronal death after hemorrhagic stroke in vitro and in vivo shares features of ferroptosis and necroptosis. Stroke 48, 1033-1043. doi: 10.1161/STROKEAHA.116.015609

Conflict of Interest: The authors declare that the research was conducted in the absence of any commercial or financial relationships that could be construed as a potential conflict of interest.

Copyright (C) 2020 Ashraf and So. This is an open-access article distributed under the terms of the Creative Commons Attribution License (CC BY). The use, distribution or reproduction in other forums is permitted, provided the original author $(s)$ and the copyright owner(s) are credited and that the original publication in this journal is cited, in accordance with accepted academic practice. No use, distribution or reproduction is permitted which does not comply with these terms. 